\title{
State-Run Schools Reconsidered: A Reply to Merry
}

\author{
Kelly M. S. Swope (Vanderbilt University)
}

\begin{abstract}
:
In this reply, I consider some major points of Michael Merry's article, "Citizenship, Structural Inequality, and the Political Elite." Specifically, I discuss how his distinction between civic education and political education raises an important question about the relationship of state-run schooling to modern statecraft, namely, whether it is possible for state-run schools to do anything but reproduce the extant order.
\end{abstract}

Keywords:

reply

In this reply, I consider some major points of Michael Merry's article, "Citizenship, Structural Inequality, and the Political Elite." Specifically, I discuss how his distinction between civic education and political education raises an important question about the relationship of state-run schooling to modern statecraft, namely, whether it is possible for state-run schools to do anything but reproduce the extant order. I then assess his critique of the liberaldemocratic ideology underwriting state-run civic education in Western democracies, arguing that it resembles earlier liberal-democratic critiques of civic education under absolutist monarchies. I judge, as well, that Merry's critique of liberal civic education is really a critique of the political function of state-run schools in general. In response to this broader critique, I consider a proposal for state-run education in which schools would supplement the kind of political education that Merry endorses.

I agree with much of what Michael Merry says in "Citizenship, Structural Inequality, and the Political Elite." $\mathrm{He}$ is right, for example, to question the liberal premise that the primary function of state-run schools is to train a deliberative citizenry, especially in cases when such training chiefly aims at inculcating uncritical dispositions and obsequious compliance toward the state. Moreover, he is right to challenge educationists to reconcile their normative principles of how state-run schools ought to be with the realities of how schools are in most Western democracies (think of the failure of liberal democracy reflected in the school-to-prison pipeline in the United States). Most insightful of all is Merry's distinction between civic education and political education, the former being a "coercive, state-directed, curriculum-based citizenship education," (Merry, 2018, p. 4) the latter being an informal education in civil society without which "institutional reform and progress" (ibid.) would be foreclosed. If we accept such a distinction, then we also accept that existing liberal democracies require intellectual input from outside their formal processes in order to better their institutions. And if we accept this, then we also accept that state-run schools, insofar as they mainly train citizens to perpetuate the status quo, rather than critique and reform it, do more to thwart democracy than to foster it.

An important question concerning the aims of state-run schooling comes out of Merry's distinction between civic and political education. The question is: is it possible for state-run education to do anything but perpetuate the state's dominant ideology at the expense of the dominated? In existing nation-states, according to Merry, such ideology manifests in the nationalistic or xenophobic messaging that governments often insert into civics and history lessons. Students are encouraged to put their hands over their hearts at the sight of the national flag; students are taught to view their own nation, or the dominant social group within their nation, as a protagonist of world history. State-run schools additionally coach students to comply with the behavioral norms of respectable citizenship, even when such norms are not universally inclusive. Merry is skeptical that nationstates can loosen their ideological grip on education enough to let their citizens develop into critical thinkers regardless of their compliance with these kinds of norms. Indeed, students' deviance from such norms is often a cause for formal and informal censure from school authorities and even law enforcement - disproportionately so if the students are immigrant, poor, a religious or racial minority, etc.

Merry lays much of the blame for this situation at the feet of "power elites" and the liberal theorists who do their ideological bidding. He writes that we should not expect 
that citizenship education, as devised by these power political elites or academic theorists,

will permit challenges to the institutional status quo. Schools are not designed for this purpose, but rather to inculcate dispositions in pupils to 'abide by the law' and to 'support fundamental political arrangements.' And this is precisely what liberal citizenship theories exhort us to do, which renders them wittingly complicit with the political status quo (...) (Merry, 2018, p. 4)

In other words, liberal citizenship education, by failing to acknowledge the true purpose of state-run schooling, is wittingly complicit in the state's project of producing a conformist status quo that punishes non-conformism. What I find curious about Merry's critique of liberal-democratic educationists is that it resembles almost exactly the critiques by an earlier generation of liberal-democratic educationists against the state-run schools of absolutist monarchies. Consider the case of John Dewey. In German Philosophy and Politics, Dewey explains how the absolutist monarchy in Prussia, following Napoleon's exploits there, built the first modern, state-run public education system in service of the moral and spiritual regeneration of its people. It was the belief of many Prussian educational reformers that national unity in the wake of military defeat depended upon state-run schools, and it was in these schools that many Prussians received formal education for the first time. Dewey criticizes the long-term effect of this permanent public institution, which over the course of the nineteenth century authorized the state not only to provide the means of education but also its ends, as if human beings had nothing to gain from formal education except the habit of patriotism. With the establishment of this system, the Enlightenment cosmopolitan ideal of training individuals to be intellectually self-standing citizens of the world became subordinate to the political wills of kings (Dewey, 1915, pp. 72-73).

On the other hand, Dewey recognizes the irreversible growth of modern nation-states out of the old monarchies and thus the contingent necessity of working through them to spread education more widely (Dewey takes it as selfevident that increasing ordinary people's level of education is a political good). He gives Germany credit for being the first nation-state in the modern world to succeed in its construction of a public, universal, compulsory system of education extending from primary school to the university, and for submitting to jealous state regulation and supervision all private educational enterprises. Dewey affirms these achievements as advancements of the democratic ideal of educating all humanity. That said, Germany's use of public education as an instrument of nationalism arrested these advancements in the course of their natural development, and with enormous historical consequences. Reflecting on this problem, Dewey writes, in Democracy and Education:
This contradiction $(. .$.$) between the wider sphere of$ associated and mutually helpful social life and the narrower sphere of exclusive and potentially hostile pursuits and purposes, exacts of educational theory a clearer conception of the meaning of "social" as a function and test of education than has yet been attained. Is it possible for an educational system to be conducted by a national state and yet the full social ends of the educative process not be restricted, constrained, and corrupted? (Dewey, 2008, pp. 88-89)

For Dewey, writing in 1915, this is the central question that the democratic thinkers of his century ought to be asking themselves. Note how his primary concern is not for the ends of the national governments furnishing the educational institutions - it is a contingent necessity that they must oversee education - but for the "full social ends" of the educative process. By full social ends, Dewey means the cosmopolitan ends outlined by educationists such as Kant during the late Enlightenment, i.e., the education of individuals to think without the coercion of external authorities, and to see themselves as members of a free and intellectual species.

Thus, Dewey's liberal-democratic analysis of the dilemma of state-run education originates in his critique of absolutists' manipulation of public schooling for nationalistic ends. As far as I can see, there is no principled difference between his critique of absolutist education from a liberal-democratic perspective and Merry's critique of liberal-democratic education from a radical-democratic perspective. What is present in Dewey's critique that is absent from Merry's, however, is an historical accounting of the partly emancipatory effect that state-run schools had on their initial beneficiaries. The state-run school established a new point of political contact between subjects and their state. Although this did not lead to full political enfranchisement or even a free intellectual situation, it did increase literacy dramatically and contributed to the development of political consciousness among citizens who under feudal regimes did not have this kind of sustained educative contact with the state. On Merry's account, by contrast, state-run schools in the twenty-first century appear to have achieved these fundamental goals and so have exhausted their limited democratic possibilities, now serving the state more or less as disciplinary institutions and enforcers of nationalist ideology. This is significant because it means that state-run schools are no longer contributing to democratization as they ideologically and physically coerce their citizens. Indeed, even as they increase their civic-educational power in many Western countries, teaching people how their governmental systems and dominant cultures operate, they seem to have lost their wider political-educational function, thwarting the development of democratic movements instead of fostering them. In Merry's words: "Schools are not designed for this purpose, but rather to 
inculcate dispositions in pupils to 'abide by the law' and to 'support fundamental political arrangements' (Merry, 2018, p. 4)."

My question for Merry is whether this is the way the situation will always be in state-run schools, as his above comment suggests, or whether it is still a live dilemma live because, as Dewey observes, it is the educational dilemma of liberal-democratic regimes that take the nationstate form

Allow me to consider one more historical case that touches on this question: that of W.E.B. Du Bois. Du Bois was an American educationist who thought that state-run schools in liberal democracies, despite the many harms they propagated, might yet provide a supplement to organic democratic movements happening both inside and outside the nation-state's formal institutions. In his Darkwater essays, Du Bois argues that democracy requires for its proper functioning the universal epistemic inclusion of all its subjects in the affairs of state and economy. For him, this means that all political subjects in a state must be allowed to contribute what they know to "the ruling of men." One implication of his claim is that there is no such thing as getting the people ready for democracy, only doing democracy itself, in medias res. Du Bois' critical target is the power-elitist camp that thinks that a lack of the right kind of political education disqualifies ordinary people from handling the levers of political power. Dismissing their elitism, Du Bois says that "education is not a prerequisite to political control [but] political control is the cause of popular education" (Du Bois, 2016, p. 81). A body politic learns to swim by diving in the water. Merely studying the principles of government in a formal setting, especially if that setting is dominated by an exclusivist, elitist class, is not going to teach people how to rule themselves.

Still, although Du Bois claims that political education comes from political control and not the other way around, he does suggest that formal education can be a permanent institutional supplement to democratic movements. Much of Du Bois' Black Reconstruction is dedicated to developing this idea. The significance of the Reconstruction program for state-run schooling, on his view, was its reciprocity of political and educational empowerment. After the Civil War, many black freedmen immediately took on formal leadership roles in the Reconstruction government, and many more labored, through the Freedmen's Bureau, for the establishment of a public-school system in the South that could accelerate the political and intellectual uplift that had already begun after Emancipation. Their vision was not only to set up the South's first public school system for the practical ends of basic literacy and vocational training but also to make accessible to all those more complex forms of literacy that enhance their sharing of their performance of political knowledge. According to Du Bois, they saw democracy itself as an educational process of which formal schooling was but one indispensable element (Du Bois, 1935; see the chapter called "Founding of the Public Schools").

I reference Du Bois' analysis of the potential democratic upshot of state-run schools not because it alters our view of the facts about how those schools operate today - the facts are not encouraging - nor because I think it offers some secret formula to reconstructing state-run schooling in a truly democratic image. I bring him up rather to support my claim, contra Merry, that it need not be a cognitively dissonant experience, and may yet be productive, to imagine that state-run schools, despite their flaws, could foster forms of critical reflection and socialization that could supplement democratic political education in the sense Merry endorses. Du Bois argued that such a situation could obtain in nation-states provided that democratization is already underway in a much wider political context, namely, in the major institutions of state and economy. Obviously, state schools will be no exception if the rule is a domineering nationalist ideology and an exclusivist politics. Yet they are the only means we presently have to spread education as broadly as possible to as many people as possible; they retain at least this basic democratic function. Proof of this is that no serious democrat wants to let existing civil society, dominated as it is by profit-maximizing interests, complete its slow coup of public education for the private benefit of a few. If we want to prevent that catastrophic outcome, then we still have a significant political stake in state-run schools.

Merry can agree with my point, I hope, while retaining his critical assessment of the empirics about state-run schools. To my mind, that is not cognitive dissonance but dialectics. There is still some use left for Du Bois' insight from Black Reconstruction that formal education can supplement wider democratization when it furnishes an environment in which political knowledge and the means of expressing it can be freely developed. A sea-change of political will is needed to make that environment a reality, but then, so is that sea-change needed in order to begin seriously challenging the global structural inequalities against which Merry and this author struggle.

\section{References}

Dewey, J. (1915). German philosophy and politics. Holt \& Co.

Dewey, J. (2008). Democracy and education. Wilder Publications.

Du Bois, W. E. B. (2016). Darkwater. Verso Books. 
Du Bois, W. E. B. (1935). Black reconstruction in America. Free Press.

Merry, M. S. (2018). Citizenship, structural inequality and the political elite. On Education. Journal for Research and Debate, 1(1). https://doi.org/10.17899/on_ed.2018.1.1

\section{Recommended Citation}

Swope, K. M. S. (2018). State-run schools reconsidered: A reply to Merry. On Education. Journal for Research and Debate, 1(1). https://doi.org/10.17899/on_ed.2018.1.13

\section{About the Author}

Kelly M. S. Swope is a graduate student in philosophy at Vanderbilt University in the United States. He is currently at work on a dissertation about G.W.F. Hegel's philosophy of education. 